\title{
PENGARUH PENDEKATAN REALISTIC MATHEMATICS EDUCATION (RME) TERHADAP KEMAMPUAN BERPIKIR KRITIS SISWA KELAS VII SMP NEGERI 2 KOTA JAMBI
}

\author{
Rismaya Oktaviani ${ }^{1}$, Harman $^{2}$, Sri Dewi ${ }^{3}$ \\ Program Studi Pendidikan Matematika, FKIP, Universitas Batanghari ${ }^{1,2,3}$ \\ J1. Slamet Riyadi No.1 Broni Jambi \\ e-mail: -
}

\begin{abstract}
ABSTRAK
Penelitian ini dilatarbelakangi oleh kemampuan berpikir kritis siswa yang rendah. Hal ini disebabkan oleh ketidakefektifan pembelajaran di kelas dalam proses pembelajaran dengan model konvensional sedangkan siswa yang menerimanya lebih pasif dan takut untuk mengutarakan anggapan tersebut karena mereka menganggap matematika sulit untuk dipelajari. Jadi guru perlu menerapkan sistem pembelajaran yang menyenangkan dan lebih nyata dalam meningkatkan kemampuan berpikir kritis dengan menggunakan Pendekatan Pendidikan Matematika Realistik (RME) untuk membantu pemikiran kritis siswa menjadi lebih kritis. Penelitian ini adalah penelitian eksperimental. Populasi dalam penelitian ini adalah semua siswa kelas VII SMPN 2 Kota Jambi Tahun Ajaran 2017/2018. Pengambilan sampel menggunakan teknik Random Sampling, yang diambil kelas VII A dan VII D dimana dua kelas diberikan perlakuan yang berbeda. Penelitian ini bertujuan untuk mengetahui perbedaan pendekatan Pendidikan Matematika Realistik (RME) terhadap keterampilan berpikir kritis siswa kelas tujuh SMPN 2 Kota Jambi, subjek himpunan. Berdasarkan hasil Post-test dapat diketahui bahwa kemampuan berpikir kritis siswa kelas VIIIA (eksperimen) SMP Negeri 2 Kota Jambi pada materi yang ditetapkan, nilai ratarata adalah 76,84 dengan standar deviasi 6,96 sedangkan pada kelas VIIID (Kontrol) rata-rata 72.75 dengan standar deviasi 11,64. Berdasarkan perhitungan ini terdapat perbedaan antara kelas eksperimen dan kelas kontrol, ini adalah pengaruh pendekatan Realistic Mathematics Edication (RME).
\end{abstract}

\section{Kata kunci:}

Pendekatan Pendidikan Matematika Realistik (RME); Kemampuan Berpikir Kritis Siswa.

\begin{abstract}
This research is motivated by low students' critical thinking ability. This is caused by the ineffectiveness of learning in the classroom in the learning process with conventional model while the students who receive it more passive and afraid to express the assumption because they think that math is hard to learn. So teachers need to apply a fun learning system and more real in improving the ability to think critically by using Realistic Mathematics Education Approach $(R M E)$ to help critical thinking of students to be more critical. This research is an experimental research. The population in this research is all students of class VII SMPN 2 Kota Jambi Academic Year 2017/2018. Sampling using Random Sampling technique, which is taken class VII $A$ and VII $D$ where two classes are given different treatment. This study aims to determine the difference of Realistic Mathematics Education (RME) approach to critical thinking skills of the seventh grade students of SMPN 2 Kota Jambi, the subject of the set. Based on Post-test results can be seen that the critical thinking ability of students of class VIIIA (experiment) SMP Negeri 2 Kota Jambi on the set material, the average value is 76.84 with standard deviation 6.96 whereas in class VIIID (Control) average of 72.75 with standard deviation of 11.64. Based on these calculations there is a difference between the experimental class and the control class, this is the influence of the approach of Realistic Mathematics Edication (RME).
\end{abstract}

Keywords:

Realistic Mathematics Education (RME) Approach; Student Critical Thinking Ability. 


\section{PENDAHULUAN}

Perkembangan

globalisasi memberikan pengaruh yang sangat besar terhadap perkembangan suatu negara. Agar mampu bersaing menghadapi tantangan era globalisasi, maka diperlukan sumber daya manusia (SDM) yang berkualitas. Untuk membentuk sumber daya manusia yang demikian maka perlu diberikan pendidikan yang berkualitas dan beragam macam mata pelajaran. Pendidikan adalah pembelajaran, pengetahuan, keterampilan, dan kebiasaan sekelompok orang yang diturunkan dari satu generasi ke generasi berikutnya melalui pengajaran, pelatihan, atau penelitian.

Salah satu mata pelajaran yang berperan untuk pendidikan adalah matematika, karena matematika bagian dari kehidupan manusia. Mulyono (2003) mengemukakan bahwa "matematika adalah suatu cara untuk menemukan jawaban terhadap masalah yang dihadapi manusia; suatu cara menggunakan informasi, menggunakan pengetahuan tentang bentuk dan ukuran, menggunakan pengetahuan tentang menghitung, dan yang paling penting adalah memikirkan dalam diri manusia itu sendiri dalam melihat dan menggunakan hubunganhubungan". Ada beberapa tujuan dari pembelajaran matematika adalah:

1. Mempersiapkan siswa agar sanggup menghadapi perubahan keadaan dan pola pikir dalam kehidupan dan selalu berkembang.

2. Mempersiapkan siswa menggunakan matematika dan pola pikir matematika dalam kehidupan sehari dan dalam mempelajari berbagai ilmu pengetahuan.

Oleh karena itu siswa harus memiliki kemampuan memperoleh, memilih dan mengelola informasi untuk bertahan pada keadaan yang selalu berubah. Kemampuan ini membutuhkan pemikiran yang kritis, sistematis, logis, kreatif dan kemampuan bekerja sama yang efektif. Dengan demikian, maka seorang guru harus terus mengikuti perkembangan model pembelajaran matematika dan selalu berusaha agar kreatif dalam pembelajaran yang dilakukan sehingga dapat membawa siswa ke arah yang diinginkan.

Berdasarkan data yang didapat oleh penulis dengan salah satu guru mata pelajaran matematika di SMP Negeri 2 Kota Jambi, guru mengajarkan siswa dengan sistem belajar dengan pendekatan konvensional. Akan tetapi pada realitanya sistem belajar tersebut belum efektif setelah diterapkan, hal ini disebabkan oleh beberapa faktor salah satunya siswa masih pasif dalam pembelajaran tersebut karena takut untuk mengungkapkan asumsi mereka, ditambah lagi mereka ingin belajar matematika itu dibuat sedemikian rupa nyata dan mengasikkan sehingga pemikiran siswa lebih berkembang. Faktor tersebutlah yang membuat pembelajaran matematika terasa rumit dan tidak menyenangkan untuk dipelajari oleh sebagian siswa dan menjadi penyebab tidak aktifnya siswa dalam pemikiran secara kritis. Disisi lain anggapan yang saat ini berkembang pada sebagian besar peserta didik adalah matematika bidang studi yang sulit untuk di pelajari dan tidak disenangi oleh kebanyakan siswa. Hanya sedikit yang mampu mengerti dan memahami matematika sebagai ilmu yang dapat melatih kemampuan berpikir kritis disebabkan faktor di atas. Padahal dengan adanya keaktifan bertanya, menjawab pertanyaan, mengemukakan ide dan kreatifitas dalam menyelesaikan permasalahan matematika dapat melatih kemampuan berpikir kritis.

Bersandar pada permasalahan di atas, dapat disimpulkan bahwa kemampuan berpikir kritis peserta didik sangat penting untuk dikembangkan. Ada beberapa landasan dalam berpikir kritis yang mencakup kemampuan diantaranya: 


\section{$\pi$ (Phi)}

(a) mengenal masalah, (b) menemukan cara-cara yang dapat dipakai untuk menangani masalah - masalah itu, (c) mengumpulkan dan menyusun informasi yang diperlukan, (d) mengenal asumsiasumsi dan nilai-nilai yang tidak dinyatakan (e) memahami dan menggunakan bahasa yang tepat, jelas dan khas, (f) Menganalisa data, (g) menilai fakta dan mengevaluasi pernyataanpernyataan, (h) mengenal adanya hubungan yang logis antara masalahmasalah, (i) menarik kesimpulankesimpulan dan kesamaan-kesamaan yang diperlukan (j) menguji kesamaankesamaan dan kesimpulan-kesimpulan yang seseorang ambil, (k) menyusun kembali pola-pola keyakinan seseorang berdasarkan pengalaman yang lebih luas, (l) membuat penilain yang tepat tentang hal-hal dan kualitas-kualitas tertentu dalam kehidupan sehari-hari, (Rusman, 2013).

Oleh karena itu, guru hendaknya melakukan berbagai perubahan dalam pembelajaran matematika agar dapat meningkatkan berpikir siswa secara kritis salah satunya dengan menggunakan pendekatan- pendekatan yang nyata. Penggunaan pendekatan pembelajaran ini sangat penting dilakukan dalam proses belajar mengajar. Hal itu akan berdampak pada keaktifan siswa dalam berpikir saat proses pembelajaran. Untuk membuat pembelajaran matematika agar siswa lebih aktif dalam pembelajaran dapat menggunakan berbagai macam pendekatan salah satunya pendekatan Realistic Mathematics Education (RME) dimana pendekatan ini bisa diterapkan pada pembelajaran matematika karena menggunakan masalah pada kehidupan siswa sehari-hari.

Pendekatan Realistic Mathematics Education (RME) atau yang sering disebut pendekatan matematika realistik Indonesia adalah suatu pendekatan pembelajaran dalam matematika yang realistic berupa masalah yang ada di dunia nyata (real-world problem) dan bisa di kemukakan dalam kehidupan sehari-hari siswa. Realistic Mathematics Education (RME) adalah suatu pendekatan pembelajaran dalam matematika yang realistic berupa masalah yang ada di dunia nyata (real-world problem) dan bisa di kemukakan dalam kehidupan sehari- hari siswa.

Pendekatan Realistic Mathematics Education (RME) di kembangkan oleh seorang ahli matematika Freudenthal (Ariyadi, 2012), yang menegaskan bahwa matematika merupakan aktivitas manusia (human activity), dalam pembelajarannya siswa bukan hanya penerima pasif tetapi siswa perlu di beri kesempatan untuk reinvent (menemukan) matematika di kehidupan sehari-hari kepengalaman belajar sesuai dengan materi yang di sajikan. Freudenthal yang berbunyi " Mathematics is a human activity".

Menurut Freudenthal (Ariyadi, 2012) matematika sebaiknya tidak di berikan kepada siswa sebagai suatu produk yang siap di pakai, melainkan sebagai suatu bentuk kegiatan dan mengkonstruksi konsep matematika. Freudenthal mengenalkan istilah "guided reinvention" sebagai proses yang dilakukan siswa secara aktif untuk menemukan kembali suatu konsep matematika dengan bimbingan guru. Hal serupa juga di ungkapkan oleh Ahmad (2013) mengungkapkan Realistic Mathematics Education (RME) atau yang sering di kenal Pendekatan Matematika Realistis Indonesia (PMRI) merupakan salah satu pendekatan pembelajaran matematika yang berorientasi pada siswa, bahwa matematika adalah aktivitas manusia dan matematika harus dihubungkan secara nyata terhadap konteks kehidupan sehari-hari siswa kepengalaman belajar yang berorientasi pada hal-hal yang real (nyata).

Upaya ini di lakukuan melalui 


\section{$\pi$ (Phi)}

penjelajahan berbagai situasi dan persoalan-persoalan "realistik". Penggunaan kata "realistik" dalam hal ini dimaksudkan tidak hanya mengacu pada realistik tetapi pada sesuatu yang bisa di bayangkan siswa. Menurut Van den Veuvelpanhuizen (Ariyadi, 2012) penggunaan kata realistik tidak sekedar mengacuh pada fokus menunjukan adanya suatu koneksi dengan dunia nyata "real word" tetapi lebih mengacu pada fokus pendidikan matematika realistik dalam menempatkan penekanan penggunaan suatu situasi yang bisa di bayangkan (imaginable) oleh siswa. Prinsip penemuan kembali dapat di inspirasi oleh prosedur- prosedur pemecahan informal, sedangkan proses penemuan kembali menggunakan konsep kemampuan berpikir kritis matematis. Dalam Pendidikan Matematika Realistik, matematika dipandang sebagai aktivitas insani (human activity), sehingga kegiatan pembelajaran menggunakan konteks real dan menghargai gagasan-gagasan siswa, (Zulkardi, 2010). Pembelajaran matematika realistik ini membuat siswa dapat menggunakan pemikiran yang kreatif dan kritis yang lebih komplit, kemudian siswa juga dapat mengaplikasikan kemampuan berpikir mereka kedunia nyata.

\section{METODE PENELITIAN}

Penelitian ini merupakan penelitian kuantitatif dan metode penelitian yang di gunakan dalam penelitian ini adalah metode eksperimen. Dalam penelitian eksperimen ada objek atau subjek yang akan diteliti menajadi dua grup yaitu grup treatment yakni yang menerima perlakuan dan grup kontrol yang tidak memperoleh perlakuan.

Menurut Sugiyono (2011) "Populasi adalah wilayah generalisasi yang terdiri atas obyek/subyek yang mempunyai kualitas dan karakteristik tertentu yang di tetapkan oleh peneliti untuk di pelajari dan

kemudian di tarik kesimpulannya". Penelitian ini yang akan menjadi populasi adalah seluruh siswa kelas VII SMP Negeri 2 Kota Jambi tahun ajaran 2017/2018 yang terdiri dari 7 kelas.

Penarikan sampel dalam penelitian ini di lakukan secara simple random sampling atau teknik acak yaitu pengambilan sampel secara acak terhadap populasi yang ada, karena semua anggota dalam populasi mempunyai probabilitas atau kesempatan yang sama untuk dipilih menjadi sampel (Sukardi, 2003). Sampel penelitian diperoleh untuk menentukan kelompok ekperimen dan kelompok kontrol. Kelompok eksperimen menggunakan pendekatan Realistic Mathematics Education (RME), sedangkan kelompok kontrol menggunakan pembelajaran konvensional.

Selanjutnya sebelum diberikan perlakuan tentang pokok bahasan himpunan pada kelas eksperimen dan kelas kontrol, penelitian ini dilakukan pretest untuk menilai sampel sejauh mana kemampuan siswa dalam berbagai indikator sebelum mereka menerima materi pelajaran dan setelah diberi perlakuan pada kelas eksperimen dan kelas kontrol dilakukan post-test untuk menilai kelas sampel sejauh mana kemampuannya setelah menerima materi pelajaran. Sebelum soal diberikan ke kelas sampel yang terdiri dari kelas eksperimen berjumlah 32 siswa dan kelas kontrol berjumlah 32 siswa terlebih dahulu soal pre-test dan post-test divalidasi diluar kelas sampel yaiu kelas VIII B dan kelas VII $F$ agar sesuai dengan indikator kemampuan berpikir kritis.

Instrumen merupakan alat ukur yang digunakan untuk memperoleh data berupa lembaran hasil tes belajar. Tes dalam hal ini adalah alat pengumpul informasi tentang kemampuan berpikir kritis siswa. Instrumen yang digunakan dalam penelitian ini adalah tes uraian yang diberikan kepada siswa sebelum (pretest) 


\section{$\pi$ (Phi)}

dan sesudah (posttest) perlakuan terhadap kelas eksperimen dan kelas kontrol. Pemilihan berupa tes uraian itu bertujuan untuk melihat kemampuan berpikir kritis siswa dalam menjawab soal uraian. Menurut Arikunto (2010) tes esai menuntut siswa untuk dapat megingatingat dan mengenal kembali, terutama harus mempunyai daya kreativitas tinggi, sehingga tes uraian tersebut sangat cocok diterapkan untuk melihat kemampuan berpikir kritis siswa.

Data yang dianalisis pada penelitian ini adalah skor hasil pre-test dan post-test siswa kelas eksperimen dan kelas kontrol. Setelah data pre-test dan post-test di peroleh dilakukan pengolahan data pretest dan post-est kemudian dianalisis. Untuk menguji hipotesis dengan membandingkan skor rata-rata nilai siswa kelompok eksperimen dan kelompok kontrol. Metode statistic yang digunakan adalah uji kesamaan rata-rata dengan uji-t untuk menguji hipotesis dalam penelitian ini. Sebelum Analisis dilakukan terlebih dahulu dilakukan uji normalitas dan uji homogenitas.

\section{HASIL DAN PEMBAHASAN}

Setelah mendapatkan hasil yang refresentatif dari 7 kelas yaitu kelas VII A, VII B, VII C, VII D, VII E, VII F dan VII $\mathrm{G}$ dengan mengambil nilai tes kemampuan awal matematika siswa tahun ajaran 2017/2018 yang sudah layak dan dipercaya sebagai gambaran dari kondisi siswa yang sebenarnya, selanjutnya peneliti melakukan Uji Normalitas, Uji Homogenitas, dan Uji Kesamaan Ratarata (ANAVA). Berikut ini tabel hasil uji kesamaan rata-rata (ANAVA)

Tabel 1. Nilai Rata-rata dan Simpangan Baku Nilai Pre-Test

\begin{tabular}{cccc}
\hline Kelas & $\begin{array}{c}\text { Jumlah } \\
\text { Siswa }\end{array}$ & Rata-rata & $\begin{array}{c}\text { Simpangan } \\
\text { Baku }\end{array}$ \\
\hline Eksperimen & 32 & 76,84 & 6,96 \\
Kontrol & 32 & 72,75 & 11,64 \\
\hline
\end{tabular}

Dari tabel uji pre-test di atas menunjukkan untuk rata-rata kelas eksperimen adalah 38,84 dengan simpangan bakunya adalah 17,81 dan ratarata kelas kontrol adalah 42,55 dengan simpangan bakunya adalah 14,24.

Tabel 2. Nilai Rata-rata dan Simpangan Baku Nilai Post-Test

\begin{tabular}{cccc}
\hline Kelas & $\begin{array}{c}\text { Jumlah } \\
\text { Siswa }\end{array}$ & Rata-rata & $\begin{array}{c}\text { Simpangan } \\
\text { Baku }\end{array}$ \\
\hline Eksperimen & 32 & 38,84 & 17,81 \\
Kontrol & 32 & 42,55 & 14,24 \\
\hline
\end{tabular}

Pengolahan datanya dilakukan secara manual menggunakan kalkulator dan secara otomatis menggunakan Microsoft Exel. Sebelum diberikan perlakuan kedua kelas sampel diberikan pre-test tentang materi himpunan. Dalam penelitian ini dilakukan pre-test adalah untuk menilai sampai sejauh mana kemampuan siswa dalam berbagai indikator sebelum mereka menerima materi pelajaran.

Untuk uji normalitas ini tujuannya untuk melihat apakah sampel berasal dari populasi berdistribusi normal atau tidak. Uji Normalitas data hasil pre-test kemampuan berpikir kritis siswa kelas eksperimen dan kontrol. Dapat dilihat pada tabel berikut:

Tabel 3. Hasil Uji Normalitas Pre-Test Kemampuan Berpikir Kritis

\begin{tabular}{ccccl}
\hline $\begin{array}{c}\text { Kelas } \\
\text { Sampel }\end{array}$ & $\mathbf{N}$ & $x_{\overline{7}}$ & $\begin{array}{c}\boldsymbol{x}_{\bar{\tau}}^{\frac{\alpha}{\alpha}} \\
\boldsymbol{\alpha}=\mathbf{5 \%}\end{array}$ & Ket \\
\hline Eksperimen & 32 & 6,5047 & 7,81 & Normal \\
Kontrol & 32 & 7,33 & 7,81 & \\
\hline
\end{tabular}

Dari tabel tersebut jelaslah bahwa ada peningkatan dari table tersebut $\mathrm{X}^{2}{ }_{\text {hit }}\left\langle\mathrm{X}^{2}{ }_{\mathrm{t}}\right.$ berdistribusi normal. Uji normalitas data hasi post-test kemampuan berpikir kritis siswa kelas eksperimen dan kelas kontrol, dapat dilihat pada tabel berikut ini: 


\section{$\pi$ (Phi)}

Tabel 4. Hasil Uji Normalitas Post-Test Kemampuan Berpikir Kritis

\begin{tabular}{ccccl}
\hline $\begin{array}{c}\text { Kelas } \\
\text { Sampel }\end{array}$ & $\mathbf{N}$ & $x_{\overline{7}}$ & $\begin{array}{c}\boldsymbol{x}_{\bar{F}}^{\frac{\pi}{2}} \\
\boldsymbol{\alpha}=\mathbf{5 \%}\end{array}$ & Ket \\
\hline Eksperimen & 32 & 2,40 & 7,81 & Normal \\
Kontrol & 32 & 7,0 & 7,81 & \\
\hline
\end{tabular}

Dari tabel tersebut jelaslah bahwa ada peningkatan dari table tersebut $\mathrm{X}^{2}{ }_{\text {hit }}<\mathrm{X}^{2}{ }_{\mathrm{t}}$ berdistribusi normal.

Uji homogenitas yang digunakan adalah uji F. Uji ini digunakan untuk mengetahui tiap kelas homogen atau tidak. Menguji homogenitas data hasil pre-test kemampuan berpikir kritis pada kelas eksperimen dan kelas kontrol.

Tabel 5. Hasil Uji Homogenitas Pre-Test Kemampuan Berpikir Kritis

\begin{tabular}{cccccc}
\hline \multicolumn{2}{c}{ Varians } & & & & \\
\cline { 1 - 4 } Eksp. & Kontrol & $\boldsymbol{\alpha}$ & $\mathbf{F}_{\text {hit }}$ & $\mathbf{F}_{\text {tab }}$ & Ket \\
\hline 4,22 & 3,77 & $5 \%$ & 1,12 & 1,84 & Homogen \\
\hline
\end{tabular}

Dari tabel di atas terlihat bahwa $F_{\text {hitung }}<\mathrm{F}_{\text {tabel }}$ sehingga dapat disimpulkan bahwa tidak ada perbedaan varians antara kedua kelas tersebut.

Menguji homogenitas data hasil post-test kemampuan berpikir kritis pada kelas eksperimen dan kelas kontrol. Dapat dilihat pada tabel berikut:

Tabel 6. Hasil Uji Homogenitas Post-Test Kemampuan Berpikir Kritis

\begin{tabular}{cccccc}
\hline \multicolumn{2}{c}{ Varians } & & & & \\
\cline { 1 - 5 } Eksp. & Kontrol & $\boldsymbol{\alpha}$ & $\mathbf{F}_{\text {hit }}$ & $\mathbf{F}_{\text {tab }}$ & Ket \\
\hline 2,48 & 3,35 & $5 \%$ & 1,35 & 1,84 & Homogen \\
\hline
\end{tabular}

Dari tabel di atas terlihat bahwa $F_{\text {hitung }}<\mathrm{F}_{\text {tabel }}$ sehingga dapat disimpulkan bahwa tidak ada perbedaan varians antara kedua kelas tersebut.

Teknik statistik yang digunakan untuk menguji hipotesis adalah uji pergaruh selisih dua rata-rata dengan menggunakan uji-t. hasil uji selisih dua rata-rata antara pre-test dan post-test pada kelas eksperimen dan kontrol terlihat dengan taraf nyata $\alpha=5 \%$ dan df $=62$ maka didapat $0,42<1,67$. Karena thitung lebih rendah $\mathrm{t}_{\text {tabel, }}$ maka $\mathrm{H}_{0}$ diterima.

Berdasarkan hasil Post-test dapat dilihat bahwa kemampuan berpikir kritis siswa kelas VIII $^{\mathrm{A}}$ (eksperimen) SMP Negeri 2 Kota Jambi pada materi himpunan, nilai rata-ratanya adalah 76,84 dengan simpangan baku 6,96 sedangkan pada kelas VIII ${ }^{\mathrm{D}}$ (Kontrol) memiliki ratarata 72,75 dengan simpangan baku 11,64. Berdasarkan perhitungan tersebut terdapat perbedaan antara kelas eksperimen dan kelas kontrol, hal ini merupakan pengaruh dari pendekatan Realistic Mathematics Edication (RME).

Berdasarkan data hasil selisih pretest - post-test, maka didapatkan hasil analisis data dimana kelas eksperimen mempunyai selisih rata-rata 50,8875 dan pada kelas kontrol mempunyai selisih rata-rata 46,1525. Berdasarkan perhitungan uji $t$ didapat thitung sebesar 0,42 dan $t_{\text {tabel }}$ sebesar 1,671 ternyata $t_{\text {hitung }}$ $<t_{\text {tabel }}$. Hal ini menunjukkan bahwa pendekatan Realistic Mathematics Education (RME) memberikan pengaruh dalam kemampuan berpikir kritis pada siswa SMP Negeri 2 Kota Jambi.

Hal ini disebabkan oleh proses pembelajaran dengan menggunakan pendekatan Realistic Mathematics Education (RME) lebih efektif di bandingkan pembelajaran konvensional. Dimana siswa mengalami keaktifan disetiap melaksanakan kegiatan belajar mengajar. Sebenarnya, dengan menggunakan pendekatan ini siswa dilatih untuk aktif berinteraksi dan mampu mengutarakan ide maupun gagasan baik secara lisan maupun tulisan pada masalah nyata siswa, serta membiasakan siswa berpikir kritis pada suatu permasalahan.

Namun untuk melaksanakan proses pembelajaran dengan menggunakan Pendekatan Realistic Mathematics Education (RME) lebih efektif lagi sebaiknya memenuhi beberapa kriteria, diantaranya:

1. Waktu pelaksanaan yang relatif lebih lama, sehingga siswa mampu memahami 


\section{$\pi$ (Phi)}

semua materi yang di pelajari;

2. Pendekatan ini pada dasarnya menekankan pada interaksi antar siswa agar mampu mengkomunikasikan dan mengutarakan gagasan atau ide dalam suatu permasalahan, dalam proses pembelajaran ini sebaiknya tidak didominasi oleh siswa yang mahir berbicara dan pintar saja, melainkan semua siswa harus berinteraksi sehingga membuat siswa lain merasa minder;

3. Sebaiknya suasana kelas harus kondusif, sehingga siswa tidak sulit untuk berkonsentrasi.

Dengan demikian penggunaan Realistic Mathematics Education (RME) dalam proses belajar mengajar memberikan pengaruh yang signifikan terhadap kemampuan berpikir kritis.

\section{SIMPULAN DAN SARAN}

Bedasarkan pada hasil penelitian yang telah dilakukan dapat diambil kesimpulan bahwa berdasarkan kemampuan berpikir kritis matematika siswa yang diajarkan dengan menggunakan pendekatan Realistic Mathematics Education (RME), jauh secara signifikan dengan menggunakan pendekatan Realistic Mathematics Education (RME) dibandingkan dengan menggunakan pembelajaran konvensional.

Terdapat beberapa kelebihan dalam proses pembelajaran dengan menggunakan pendekatan Realistic Mathematics Education (RME) lebih efektif,diantaranya:

1. Dalam pelaksanaannya membutuhkan waktu yang relatif lama, tetapi siswa mampun berinteraksi dengan cepat pada materi yang di pelajari dalam setiap proses pembelajaran.

2. Tidakhanya didominasi siswa yang suka berbicara ataupun yang pintar, namun siswa yang pemalu mampu berbicara dengan baik.

3. Siswa mampu berperan menjadi

layaknya guru baik siswa yang lainnya begitupun sebaliknya sehingga semua memahami materi yang akan disampaikannya.

4. Kondisi pelaksanaan proses pembelajaran lebih aktif, dikarnakan semua siswa berdiskusi dengan aktif.

\section{DAFTAR PUSTAKA}

Aunurrahman, 2011. Belajar dan Pembelajaran. Bandung: Alpabeta Arikunto, Suharsimi. 2006. Prosedur Penelitian Suatu Pendekatan praktik Edis Revisi 2006. Jakarta: Rineka Cipta.

Arikunto, Suharsimi. 2010. Prosedur Penelitian Suatu Pendekatan Praktik Edisi Revisi 2010. Jakarta: Rineka Cipta.

Daryanto. 2010. Belajar dan Mengajar. Bandung: CV Yrama widya

Etika, Indah. 2015 Pengaruh Penerapan Pendekatan Pendidikan

Matematikan Realistik Indonesia Berbantuan Sofware Wingoum Terhadap Kemampuan Spasial Siswa Kelas IX SMP Negeri 17 Kota Jambi. Tidak diterbitkan, Jambi: Program Sarjana FKIP Universitas Jambi.

Fisher, Alec. 2008. Berpikir Kritis ( Critical Thinking), Jakarta: Erlangga.

Lestari, Eka L. dan Yudhanegara M. R. 2015. Penelitian Pendidikan Matematika. Bandung: PT Refika Aditama.

Mulyono Abdurrahman, Pendidikan bagi Anak Berkesulitan Belajar, (Jakarta: Rineka Cipta, 2003), hal. 252.

Rusman, 2013. Jurnal.co.id/2013/ jurnal pendidikan vol. 3 nomor 5

Sagala, syaiful. 2010. Konsep dan makna pembelajaran. Bandung: Alfabeta.

Sudjana, 2005. Metoda Statistika. Bandung: PT Tarsito

Sudijono, Anas, 2009. Statistic 
Pendidikan. Jakarta: PT Raja Grapindo Persada.

Sugiyono. 2015. Metode Penelitian Pendidikan kuantitatif, Kualitatif, dan $R \& D$. Bandung: Alfabeta

Sukardi, 2003. Metodologi Penelitian Pendidikan, Jakarta: Bumi Aksara

Susanto, Ahmad. 2013. Teori Belajar Pembelajaran. Jakarta: PT Kencana Prenada Group

Wijaya, Ariyadi. 2012. Pendidikan Pembelajaran Realistik: Suatu Alternatif pendekatan Pembelajaran Matematika. Yogyakarta: Graha Ilmu

Zukardi, 2010. Journal On Mathematics education Volume 1 No. 1 Juli 2010. Palembang

Usman, Basyiruddin. Metodologi Pembelajaran Agama Islam.

Jakarta: Ciputat Pers. 2002.

Wijaya, Ariyadi. 2012. Pendidikan Pembelajaran Realistik: Suatu Alternatif pendekatan Pembelajaran Matematika. Yogyakarta: Graha Ilmu.

Yamin, Martinis. 2013: Paradigma Baru Pembelajaran. Jakarta: Referensi. 